\title{
BRAND OF THE EMPLOYER AS DNA OF CORPORATE CULTURE OF SERVICE COMPANY
}

\author{
Borodai V. (Russian Federation) \\ БРЕНД РАБОТОДАТЕЛЯ КАК ДНК КОРПОРАТИВНОЙ КУЛЬТУРЫ \\ СЕРВИСНОЙ КОМПАНИИ \\ Бородай В. А. (Российская Федерация)
}

\author{
Бородай Владимир Александрович / Borodai Vladimir - доктор сочиологических наук, профессор, \\ направление: экономические науки, \\ кафедра сервиса, туризма и индустрии гостеприимства, \\ Донской государственный технический университет, г. Ростов-на-Дону
}

\begin{abstract}
: the author discloses close interrelation of such categories as a brand of the employer and corporate culture of service company. The corporate culture has to play a key role in formation of a successful brand of the employer while the brand has to consider and set cultural nuances which do this company other than others. Success in this area is defined by the presence of a well-articulated strategy, which is approved and supported by top management, as well as the availability of the necessary resources for its implementation.

Аннотация: автор раскрывает тесную взаимосвязь таких категорий как бренд работодателя и корпоративная культура сервисной компании. Корпоративная культура должна играть ключевую роль 8 формировании успешного бренда работодателя, в то время как бренд должен учитывать и закреплять культурные нюансы, которые делают данную компанию отличной от других. Успех в этой сфере определяется наличием четко сформулированной стратегии, которая одобряется и поддерживается высшим руководством, а также наличием необходимых ресурсов для ее реализачии.
\end{abstract}

Keywords: brand, corporate culture, employer, strategy.

Ключевье слова: бренд, корпоративная культура, работодатель, стратегия.

Branding of the employer gives a unique opportunity to make corresponding changes to corporate culture, namely to her identity and an image, and to create idea of service company as about the place where everyone would like to work. Many tried and try to make it, but not at all it turns out. Such situation is connected, in our opinion with the problems arising in the course of strategy realization.

Very often top management of the company declares that they have developed new strategy of creation of a brand of the employer. They consider that at a development stage of this strategy everything comes to an end, however it far not so, the main problems begin at her embodiment in life. Here not the full list of the most often found problems: strategy doesn't play an important role in internal life of the company, she is used only for hiring of workers; strategy has been created at the main office of the company without specifics of various markets, and also without discussion of details of her embodiment; heads didn't take part in creation of this strategy therefore in her embodiment they have no special enthusiasm; there is no clear trail that it will be possible to convince linear managers of need and efficiency of this strategy; the corporate culture in Europe where the concept of a brand of the employer has appeared, has the features and differs from our, Russian corporate culture.

As such categories as a brand of the employer and corporate culture correspond. The brand of the employer and corporate culture of service company are closely connected. The last has to play a key role in formation of a successful brand of the employer while the first has to consider and set cultural nuances which do this company other than others. In other words, the corporate culture is primary during creation of a brand of the company. If to consider the organization as complete system which is subject to influence of external and internal factors and changing under their influence then it is possible to assume existence of such condition of system (company) at which the effect of synergy appears. "In terms of the synergetic theory it is possible to tell that the social system is in continuous change, casual changes of institutional forms (fluctuation) - a chaos indicator at the microlevel of system and a possibility of her development. Some fluctuations turn out so strong that cause high-quality change, setting a trajectory of future development" [1]. Branding of the employer gives the chance to make changes to corporate culture of the company and to create her unique image. The brand of the employer has to reflect the cultural facts of the separate organization accurately. These facts can, both to attract applicants, and to seem to them not absolutely attractive. What attracts the applicant to a position in the Goldman Sachs company can absolutely differ from that cultural DNA which forces the applicant to wish to find work in such successful companies as Virgin, Sodexo, Apple and Zappos. These brands with solid reputation have put a lot of effort to define the main cultural markers which have brought them success and used them for increase in indicators of efficiency and also to create an image of the company, other than others.

The brand of the employer has to reflect the cultural facts of the separate organization accurately. The solid, "correct" companies have enough courage not to homogenize the culture. They understand that some applicants 
won't be attracted by their initiatives of branding of the employer. However they pay enough attention to the strategy directed to involvement of target audience on telling it why it is worth working for this company [2], [6]. The best brands don't need many applicants, they need only the best of them.

Transformation of corporate culture can take a lot of time. In the presence of such variable indicators as the size of the company, its structure, branch in which she works, life cycle of the company etc. success in this sphere is defined by existence of accurately formulated strategy which is approved and supported by the top management, and also existence of necessary resources for her realization [3], [4]. For increase in chances of success and efficiency it is necessary to perform the following operations, in our opinion:

- all interested persons have to participate in process of data collection and development of strategy of creation of a brand of the employer, and also to obtain all necessary information in the course of her realization;

- to develop accurate instructions for the heads responsible for strategy realization, assessment of its efficiency and the reporting;

- top management has to understand what advantages branding of the employer gives the companies, - it will help to increase value of strategy at all levels of the company;

- to integrate the strategy of branding of the employer into the standard procedure of business planning;

- the head of department of branding of the employer has to have a voice in executive body of the company.

Summing up the result of conceptual approach to branding of service company it should be noted the following. It is necessary to understand accurately the purposes which intentions to reach employers in the course of realization of strategy of branding have. To define that success in this area means to the employer, and of course to watch that the executive body (management) of the company controlled the embodiment of this strategy in life [5].

\section{References}

1. Boroday V. A. Trade as a social process of innovation and a factor of social transformation // Humanitarian and socio-economic sciences, 2008. № 4. P. 181-184.

2. Boroday V.A. Increased business potential based on Business Intelligence technologies // Technology Business in Russia: Theory and practice, IV Int. scientific-practical. Conf. (27 September 2016), Saratov: Publishing House MTC "Business Academy", 2016. 46 p.

3. Boroday V. A.,_Petrenko A. S. Talented rabotnikam-of benefits loyalty foundation in the service company // Summing up the year. Questions of political science, sociology, philosophy, history, economics: mezhd.nauch.-pract. Conf. (22 December 2016), Saratov: Publishing House MTC "Business Academy", 2016. 266 p.

4. Borodai V. A. Socio-societal analysis of institutional sphere of trade in today's society: thesis for the degree of Doctor of Social Sciences. Novocherkassk 2009.

5. Borodai V. A. Evolution of the service management system in the XXI century: the congruence of artificial intelligence and creativity // Science Today: postulates of the past and the modern theory: V int. ScientificPractical Conf. 2016 Saratov: Publishing House MTC "Business Academy", 2016. S. 3-7.

6. Bochkareva V. A. Marketing customer benefits as a new paradigm producer of cultural and leisure services // Economy and Society, 2015. № 6-1 (19). P. 381-384. 